\title{
Influence of hydrothermal conditions on the phase composition of materials from the system $\mathrm{MgO}-\mathrm{Al}_{2} \mathrm{O}_{3}-\mathrm{SiO}_{2}-\mathrm{H}_{2} \mathrm{O}$
}

\author{
Ryszard Prorok $^{1}$ (D) Dominika Madej ${ }^{1}$
}

Received: 24 January 2019 / Revised: 30 July 2019 / Accepted: 21 August 2019 / Published online: 7 September 2019

(C) The Author(s) 2019

\begin{abstract}
This work directly links the performance with the phase evolution in the $\mathrm{MgO}-\mathrm{Al}_{2} \mathrm{O}_{3}-\mathrm{SiO}_{2}-\mathrm{H}_{2} \mathrm{O}$ system during the hydrothermal treatment. Cement-free refractory binders, considered as alternative to calcium aluminate cements, with the chemical compositions fine-grained mixtures of $\mathrm{MgO}-\mathrm{Al}_{2} \mathrm{O}_{3}, \mathrm{MgO}-\mathrm{Al}_{2} \mathrm{O}_{3}-\mathrm{SiO}_{2}$, and $\mathrm{MgO}-\mathrm{SiO}_{2}$ reactive powders were subjected conversion from dry mixture to hydrated matrix at ca. $240{ }^{\circ} \mathrm{C}$ under autogenous water vapor pressure for $56 \mathrm{~h}$. The main purpose of this approach is to simulate the thermal behavior of the hydrated castable matrix belonging to the $\mathrm{MgO}-\mathrm{Al}_{2} \mathrm{O}_{3}-\mathrm{H}_{2} \mathrm{O}, \mathrm{MgO}-\mathrm{Al}_{2} \mathrm{O}_{3}-\mathrm{SiO}_{2}-\mathrm{H}_{2} \mathrm{O}$, and $\mathrm{MgO}-\mathrm{SiO}_{2}-\mathrm{H}_{2} \mathrm{O}$ systems when exposed to heat treatment of large-format precast monolithic refractories. The phase compositions of the hydrated samples were determined by X-ray diffraction (XRD) technique using CuK $\alpha$ radiation. The FT-IR scans were used to evaluate the functional groups of the hydrated materials. Thermal decomposition mechanism and microstructure were examined by coupled DSC-TG-EGA (MS) and SEM-EDS, respectively. It is shown through presented results that boehmite $(\mathrm{AlO}(\mathrm{OH}))$, brucite $\left(\mathrm{Mg}(\mathrm{OH})_{2}\right)$, and magnesium- and aluminum-layered double hydroxide-like phase $\left(\left[\mathrm{Mg}_{6} \mathrm{Al}_{2}(\mathrm{OH})_{18} 4.5 \mathrm{H}_{2} \mathrm{O}\right]\right)$ were formed via hydrothermal synthesis in the $\mathrm{MgO}-\mathrm{Al}_{2} \mathrm{O}_{3}-\mathrm{H}_{2} \mathrm{O}$ system. Chrysotile $\left(\mathrm{Mg}_{3}\left[\mathrm{Si}_{2-x} \mathrm{O}_{5}\right](\mathrm{OH})_{4-4 x}\right)$ was detected in the $\mathrm{MgO}-\mathrm{SiO}_{2}-\mathrm{H}_{2} \mathrm{O}$ binder system as a main phase and in the $\mathrm{MgO}$ (rich) $-\mathrm{Al}_{2} \mathrm{O}_{3}-\mathrm{SiO}_{2}-\mathrm{H}_{2} \mathrm{O}$ binder system as secondary phase. For the sample with the $\mathrm{Al}_{2} \mathrm{O}_{3}$ excess, two magnesium aluminum silicate hydroxides $\left((\mathrm{Mg}, \mathrm{Al})_{6}(\mathrm{Si}, \mathrm{Al})_{4} \mathrm{O}_{10}(\mathrm{OH})_{8}\right.$, $\left.\mathrm{Mg}_{5} \mathrm{Al}_{2} \mathrm{Si}_{3} \mathrm{O}_{10}(\mathrm{OH})_{8}\right)$, together with $\mathrm{MgAl}(\mathrm{OH})_{14} \mathrm{xH}_{2} \mathrm{O}, \mathrm{Mg}(\mathrm{OH})_{2}$, and $\mathrm{AlO}(\mathrm{OH})$, were formed in the $\mathrm{MgO}_{2} \mathrm{Al}_{2} \mathrm{O}_{3}($ rich)$\mathrm{SiO}_{2}-\mathrm{H}_{2} \mathrm{O}$ binder system. Since the type of hydrates contributed to the thermal stability of the binder matrixes, the valuable practical results concern mainly on the optimization of heat treatment process of state-of-the-art $\mathrm{CaO}$-free matrixes being considered as precursors in the low-temperature synthesis of high refractory phases like spinel and forsterite.
\end{abstract}

Keywords Binding materials $\cdot$ Hydrothermal treatment $\cdot$ Reactive oxides $\cdot$ Refractory materials

\section{Introduction}

Aluminum, magnesium, and silicon oxides are one of the main raw materials for refractory industry. Traditionally, aluminum oxide (alumina), magnesium oxide (magnesia), and silicon oxide (silica) are used in shaped refractory materials in the oxide form or as components of many refractory phases. Alumina and silica are also very popular raw materials in castables, although magnesia has also recently increased in popularity in this application as a result of the growing

Ryszard Prorok

rprorok@agh.edu.pl

1 Department of Ceramics and Refractories, Faculty of Materials Science and Ceramics, AGH University of Science and Technology, al. A. Mickiewicza 30, 30-059 Krakow, Poland popularity of basic castables. Although the use of these oxides as aggregates in refractory castables is well characterized, there is still a lack of knowledge about their behavior as hydraulic binding materials during a heat treatment.

Increased interest in binding materials based on reactive oxide powders is connected with the trend towards resignation from cements, especially calcium aluminate cements which is still one of the main raw materials for refractory castables. Calcium aluminate cements consist of calcium oxide which can form low melting phases at a higher temperature $[1,2]$. Calcium aluminate cement can be successfully replaced by binding materials based on reactive magnesium, aluminum, and silicon oxides in powder as well as in colloidal suspension. In the $\mathrm{Al}_{2} \mathrm{O}_{3}-\mathrm{MgO}-\mathrm{SiO}_{2}$ system, we can obtain different binding materials depending on its chemical composition. Those materials, based on several hydraulic phases like $\mathrm{M}$ S-H phase, M-A-S-H phase $\left(\mathrm{M}=\mathrm{MgO}, \mathrm{A}=\mathrm{Al}_{2} \mathrm{O}_{3}, \mathrm{~S}=\mathrm{SiO}_{2}\right.$, 
$\mathrm{H}=\mathrm{H}_{2} \mathrm{O}$ ), brucite, double magnesium aluminum hydroxide, and gibbsite, can be successfully utilized in many kinds of castables [3-5]. These phases can play a meaningful role in synthesis of spinel and forsterite on early stage of firing process and facilitate formation of ceramic bond [6].

There are many works on the behavior of binding materials based on the reactive oxides $\mathrm{MgO}, \mathrm{Al}_{2} \mathrm{O}_{3}$, and $\mathrm{SiO}_{2}$ in reaction with water but the influence of water vapor pressure on changes that take place during a heat treatment of the binding materials is not yet widely understood. This aspect is particularly important in the refractory castables based on this type of binders. The aim of this study was to evaluate the behavior of hydraulic binding materials based on mix magnesia, alumina, and silicon oxides, under elevated temperature and water vapor pressure conditions.

\section{Experimental}

High-purity, reagent grade magnesium oxide powder $(\mathrm{MgO} \geq$ 98\% from Acros Organics), commercial reactive alumina powder $\left(d_{50} \leq 1 \mu \mathrm{m}, \mathrm{RG} 4000\right.$ from Alamtis), and microsilica $\left(\mathrm{SiO}_{2} \geq 98 \%\right.$ Microsilica $971 \mathrm{U}$ from Elkem) were used as raw materials. Powders of the raw materials were mixed in different mass ratios and homogenized. After homogenization, the mixtures were subjected to hydrothermal synthesis at the temperature of $240{ }^{\circ} \mathrm{C}$ under autogenous water vapor pressure for $56 \mathrm{~h}$. The sample compositions are presented in Table 1. The samples, obtained after a hydrothermal treatment, were washed several times with cold acetone to remove the free water and then examined. The samples were examined by thermal analysis DSCTGA-EGA in the range from 20 up to $1000{ }^{\circ} \mathrm{C}$ (Netzsch STA 449 F5 with QMS 403D), XRD analysis carried out in range 5$90^{\circ} 2 \theta$ (Philips PanalyticalX'Pert-Pro), FTIR analysis performed in MIR range (Brucker $70 \mathrm{~V}$ ), and SEM-EDS analysis (Nova Nano SEM 200 Fei with EDAX EDS analyzer).

\section{Results and discussion}

According to XRD analysis shown in Fig. 1 and summarized in Table 2, the phase composition is quite varied. The results

Table 1 Samples composition

\begin{tabular}{cccc}
\hline & \multicolumn{3}{l}{ Composition (\% mas.) } \\
\cline { 2 - 4 } Sample designation & $\mathrm{Al}_{2} \mathrm{O}_{3}$ & $\mathrm{MgO}$ & $\mathrm{SiO}_{2}$ \\
\hline 11 & 71.20 & 28.73 & - \\
12 & 10.00 & 85.00 & 5.00 \\
13 & - & 57.11 & 42.88 \\
15 & 85.00 & 10.00 & 5.00 \\
\hline
\end{tabular}

of the analyses of samples after a hydrothermal treatment indicate the presence of different kinds of hydroxides and oxide hydroxide. In each sample, XRD analysis shows brucite in different amounts depending on the sample's chemical composition. In the case of samples with the presence of $\mathrm{SiO}_{2}$ (samples 12, 13, 15), phases from serpentine group (chrysotile) as well as mixed chlorite-serpentine group (with some substitutions of aluminum) can be identified. In sample 13 , the evidence of presence of the MSH phase, three wide effects in range $2 \theta=15-30^{\circ}, 2 \theta=35-39^{\circ}, 2 \theta=58-62^{\circ}$ can also be observed [7]. In samples 13 and $15, \mathrm{MgO}$ can be identified. The presence of $\mathrm{MgO}$ is unexpected but can be connected with the anti-hydration properties of microsilica.

The XRD patterns of the samples with $\mathrm{Al}_{2} \mathrm{O}_{3}$ (samples 11, $12,15)$ reveal boehmite but there was no evidence of the gibbsite presence, although it would be an expected phase in reaction of $\mathrm{Al}_{2} \mathrm{O}_{3}$ with water under atmospheric pressure [8]. In the place of gibbsite, magnesium aluminum hydroxide hydrate can be identified but its amount is rather low in respect to boehmite. The absence of gibbsite may indicate that during the hydrothermal treatment of the studied binders (e.g., inside castables), boehmite rather than gibbsite is formed. Gibbsite that has already been created probably transforms into boehmite or reacts with brucite to form double hydroxide, a new compound with a layered character. This would generally be positive in regard to application of these binders in the refractory castables, due to the lesshydrated character of this phases and elongated time of water evacuation from the material.

In the presence of carbon dioxide, double hydroxide magnesium and aluminum can probably form hydrotalcite-like minerals [9] but on XRD spectra in studied samples there was no evidence of such a reaction although it should be emphasized that hydrotalcite produces a similar XRD spectrum to double magnesium-aluminum hydroxide.

These findings were confirmed by a thermal analysis. As it is shown on the thermal curves in Fig. 2, different kinds of water occur in all samples, and it is also confirmed by the IR spectra. Water released in the endothermic effect in the temperature range around $100-150{ }^{\circ} \mathrm{C}$ can be connected with free water but in this range, zeolitic water can also be released [9, 10]. The amount of released water in this range slightly exceeds $2 \%$. At around $200{ }^{\circ} \mathrm{C}$, an endothermic effect occurs probably related to the decomposition of magnesium aluminum hydroxide hydrate (except sample 13) [10]. At a temperature of around $400{ }^{\circ} \mathrm{C}$, the decomposition of brucite follows, connected (in the sample with $\mathrm{SiO}_{2}$ ) with the decomposition of less thermally stable part of the MSH phase $[6,10]$. At the temperature of around $550{ }^{\circ} \mathrm{C}$, boehmite is decomposed as well [11].

The MSH phase present in sample 13 is connected with minerals from serpentine group, which can be treated as a product of transformation of the MSH phase in hydrothermal 


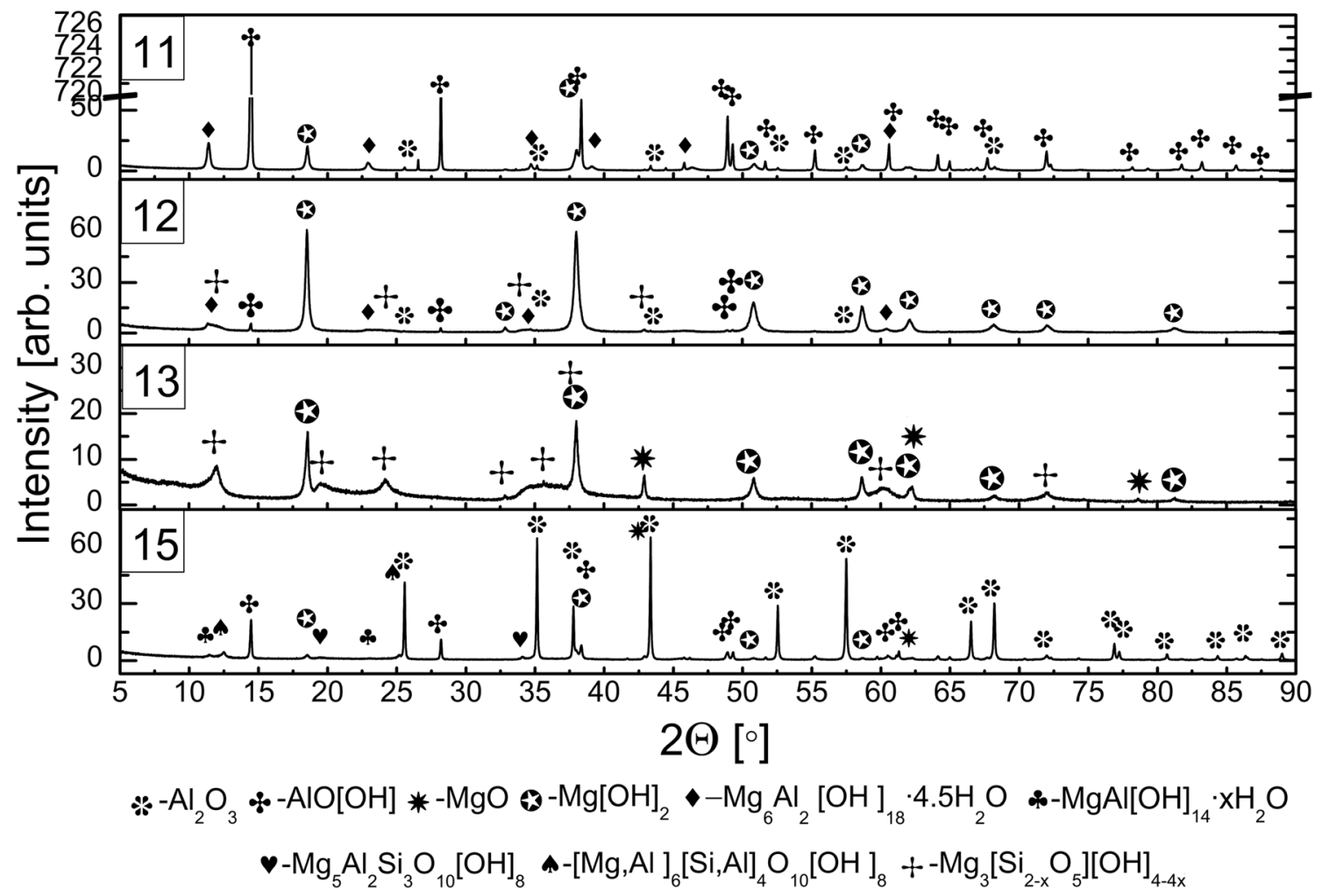

Fig. 1 XRD analysis of studied samples

conditions. Decomposition of the layer structure of serpentine minerals (sample 13) as well as serpentine-chlorite minerals (samples 12,15) is connected with the endothermic effect at around $600^{\circ} \mathrm{C}$. At a higher temperature, for sample 13, we can
Table 2 Phase composition of the studied samples

\begin{tabular}{|c|c|c|}
\hline $\begin{array}{l}\text { Sample } \\
\text { designation }\end{array}$ & Identified phases & $\begin{array}{l}\text { Reference pattern } \\
\text { by PDF }\end{array}$ \\
\hline \multirow[t]{4}{*}{11} & 1. Magnesium hydroxide (brucite) $\mathrm{Mg}(\mathrm{OH})_{2}$ & 1) $00-044-1482$ \\
\hline & 2. Magnesium aluminum hydroxide hydrate $\left[\mathrm{Mg}_{6} \mathrm{Al}_{2}(\mathrm{OH})_{18} 4.5 \mathrm{H}_{2} \mathrm{O}\right]$ & 2) $00-035-0965$ \\
\hline & 3. Aluminum oxide hydroxide (boehmite) $\mathrm{AlO}(\mathrm{OH})$ & 3) 01-074-1895 \\
\hline & 4. Aluminum oxide $\mathrm{Al}_{2} \mathrm{O}_{3}$ & 4) $01-078-2426$ \\
\hline \multirow[t]{5}{*}{12} & 1. Magnesium hydroxide (brucite) $\mathrm{Mg}(\mathrm{OH})_{2}$ & 1) $00-044-1482$ \\
\hline & 2. Magnesium aluminum hydroxide hydrate $\left[\mathrm{Mg}_{6} \mathrm{Al}_{2}(\mathrm{OH})_{18} 4.5 \mathrm{H}_{2} \mathrm{O}\right]$ & 2) $00-035-0965$ \\
\hline & 3. Magnesium silicate hydroxide (chrysotile) $\mathrm{Mg}_{3}\left[\mathrm{Si}_{2-x} \mathrm{O}_{5}\right](\mathrm{OH})_{4-4 x}$ & 3) $00-025-0645$ \\
\hline & 4. Aluminum oxide hydroxide (boehmite) $\mathrm{AlO}(\mathrm{OH})$ & 4) 01-074-1895 \\
\hline & 5. Aluminum oxide $\mathrm{Al}_{2} \mathrm{O}_{3}$ & 5) $01-078-2426$ \\
\hline \multirow[t]{3}{*}{13} & 1. Magnesium hydroxide (brucite) $\mathrm{Mg}(\mathrm{OH})_{2}$ & 1) $00-044-1482$ \\
\hline & 2. Magnesium Oxide (periclase) & 2) $00-045-0946$ \\
\hline & 3. Magnesium silicate hydroxide (chrysotile) $\mathrm{Mg}_{3}\left[\mathrm{Si}_{2-x} \mathrm{O}_{5}\right](\mathrm{OH})_{4-4 x}$ & 3) $00-025-0645$ \\
\hline \multirow[t]{7}{*}{15} & 1. Magnesium hydroxide (brucite) $\mathrm{Mg}(\mathrm{OH})_{2}$ & 1) $00-044-1482$ \\
\hline & 2. Magnesium oxide (periclase) & 2) $00-045-0946$ \\
\hline & 3. Aluminum oxide $\mathrm{Al}_{2} \mathrm{O}_{3}$ & 3) $01-078-2426$ \\
\hline & 4. Aluminum oxide hydroxide (boehmite) $\mathrm{AlO}(\mathrm{OH})$ & 4) 01-074-1895 \\
\hline & $\begin{array}{l}\text { 5. Magnesium aluminum silicate hydroxide (chlorite-serpentine) } \\
(\mathrm{Mg}, \mathrm{Al})_{6}(\mathrm{Si}, \mathrm{Al})_{4} \mathrm{O}_{10}(\mathrm{OH})_{8}\end{array}$ & 5) $00-052-1044$ \\
\hline & 6. Magnesium aluminum silicate hydroxide $\mathrm{Mg}_{5} \mathrm{Al}_{2} \mathrm{Si}_{3} \mathrm{O}_{10}(\mathrm{OH})_{8}$ & 6) 00-011-0096 \\
\hline & 7. Magnesium aluminum hydroxide hydrate $\mathrm{MgAl}(\mathrm{OH})_{14} \times \mathrm{H} 2 \mathrm{O}$ & 7) $00-043-0072$ \\
\hline
\end{tabular}




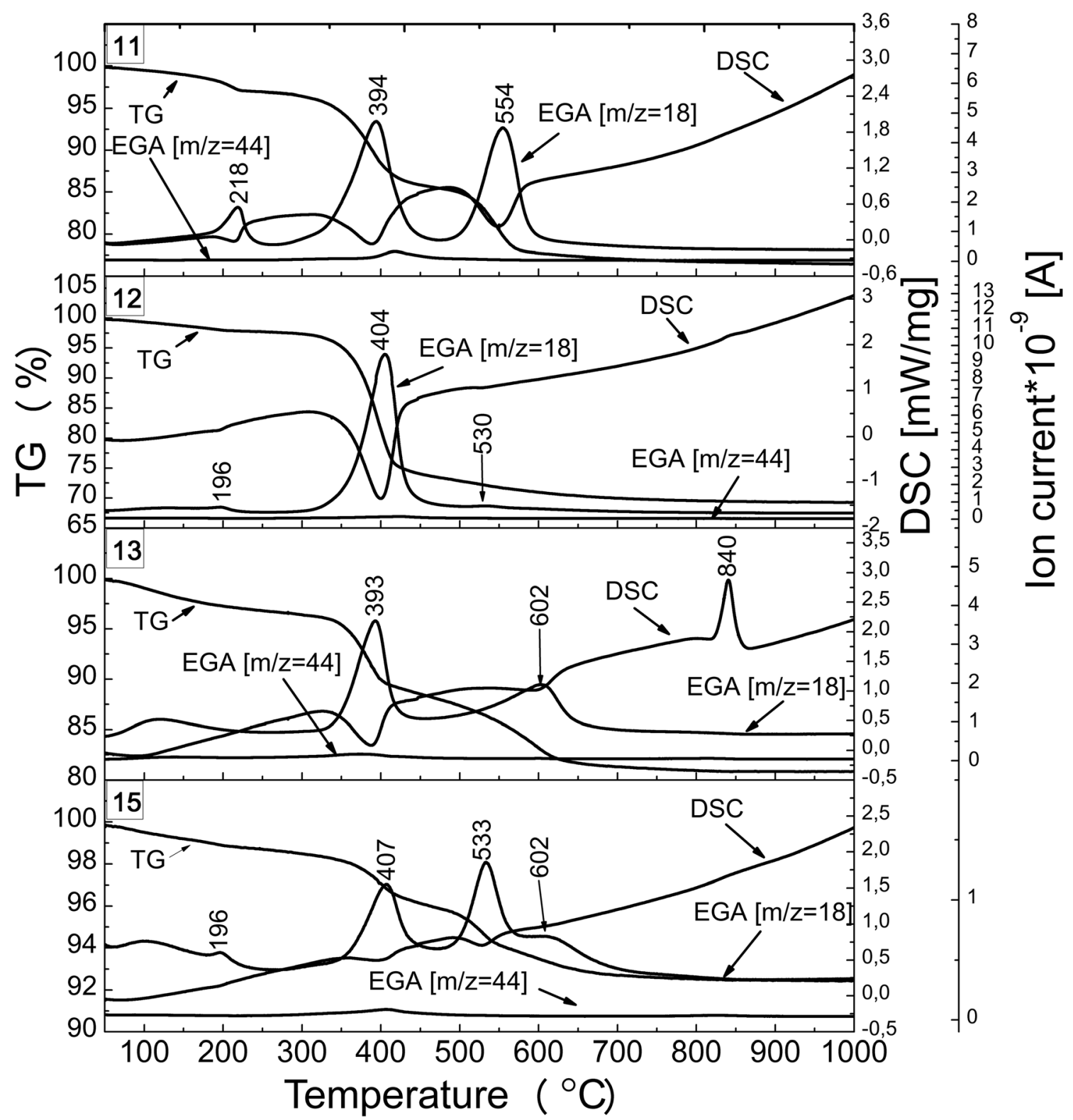

Fig. 2 Thermal analysis of studied samples

also observe an exothermic effect at a temperature of around $840{ }^{\circ} \mathrm{C}$, connected with the synthesis of magnesium silicate probably forsterite $[6,12]$. The mass changes in the temperature range, connected with the corresponding thermal effects, are presented in Table 3.

Worthy of notice is the influence of $\mathrm{SiO}_{2}$ on hydration of aluminum oxide observed (Fig. 2, Table 3) on thermogravimetric curves for samples 11,12 , and 15 . As it can be seen, the addition of $\mathrm{SiO}_{2}$ decreases the amount of double magnesium aluminum hydroxide and boehmite. This effect can be connected with anti-hydration properties of microsilica. Microsilica reacts with $\mathrm{MgO}$ creating the MSH phase which binds a part of the $\mathrm{MgO}$ and protects the rest of the magnesium oxide grains against further hydration. This process decreases the $\mathrm{pH}$ and probably influences the dissolution of $\mathrm{Al}_{2} \mathrm{O}_{3}$ as well as the amount of $\mathrm{MgO}$ that could form double hydroxide. It could be assumed that the increase in the amount of $\mathrm{MgO}$ in the sample should increase the hydration rate of $\mathrm{Al}_{2} \mathrm{O}_{3}$ while the increase in content of amorphous silica will decrease it.

Table 3 Mass losses of the samples

\begin{tabular}{clccc}
\hline $\begin{array}{l}\text { Temperature range }\left({ }^{\circ} \mathrm{C}\right) \\
\text { Sample designation }\end{array}$ & $\begin{array}{l}\text { Mass loss }(\%) \\
150-300\end{array}$ & $300-450$ & $450-650$ \\
\hline 11 & 0.92 & 2.54 & 10.58 & 8.52 \\
12 & 1.19 & 1.34 & 23.32 & 3.69 \\
13 & 2.03 & 1.57 & 7.88 & 6.84 \\
15 & 0.70 & 0.71 & 2.36 & 3.18 \\
\hline
\end{tabular}


The spectra of FTIR spectroscopy in Fig. 3 reveal several band characteristics for hydrated phases. In each sample, a sharp band of around $3700 \mathrm{~cm}^{-1}$ indicates the presence of brucite [13]. This finding is in good agreement with the thermal analysis results as well as with the results of XRD analysis. Moreover, a complex band above $3000 \mathrm{~cm}^{-1}$ can be connected with different kinds of water and vibration of $\mathrm{M}-\mathrm{OH}$ (M-metal ion) [14]. The bands around $3200-3250 \mathrm{~cm}^{-1}$ as well as $3400-3450 \mathrm{~cm}^{-1}$ are often assigned to non-structural water vibration $[15,16]$, although in the range around $3450 \mathrm{~cm}^{-1}$ according to [10] also the stretching vibrations of the $-\mathrm{OH}$ groups attached to $\mathrm{Mg}$ and $\mathrm{Al}$ ions are located. The presence of non-structural water also indicates bands in the region $1600-1700 \mathrm{~cm}^{-1}[7,10]$. Bands in the range $700-$ $1200 \mathrm{~cm}^{-1}$ can be connected with the tetrahedral layer vibration of $\mathrm{Si}(\mathrm{Al})-\mathrm{O}-\mathrm{Si}(\mathrm{Al}), \mathrm{Si}(\mathrm{Al})-\mathrm{O}$ groups $[15,17]$. The vibration around $1222 \mathrm{~cm}^{-1}$ in sample 13 is assigned to $\mathrm{Si}-\mathrm{O}$ vibration in phyllosilicates (serpentine, MSH phase) [7].

Bands around $400-650 \mathrm{~cm}^{-1}$ can be assigned to the vibrations of $\mathrm{M}-\mathrm{O}$ and $\mathrm{M}-\mathrm{OH}$ in octahedral metal layer and the vibration of tetrahedral silica layer. In samples 11,12 , and 15 , bands in the range $400-700 \mathrm{~cm}^{-1}$ can be associated with the $\mathrm{Al}_{2} \mathrm{O}_{3}$ and $\mathrm{AlO}(\mathrm{OH})$ vibrations, while in sample 13, bands in this range are assigned to the vibration of $\mathrm{Mg}-\mathrm{O}$ and $\mathrm{Si}-\mathrm{O}$, and the vibrations of oxides bridges between tetrahedral and octahedral layers in magnesium silicates hydrates [10, 18].

An interesting aspect of the studied materials is the presence of carbon dioxide especially in the samples containing $\mathrm{Al}_{2} \mathrm{O}_{3}$. FTIR analysis shows the presence of $\mathrm{CO}_{3}{ }^{2-}$ groups of around 1400 to $1500 \mathrm{~cm}^{-1}$ [15]. A sharp band around $1350 \mathrm{~cm}^{-1}$ indicates the presence of hydrotalcite-like compounds. To this compound, also bands around $1012 \mathrm{~cm}^{-1}$, $783 \mathrm{~cm}^{-1}$, and $683 \mathrm{~cm}^{-1}$ can be assigned [10, 19]. Although the hydrothermal treatment was carried out without the access of carbon dioxide, the presence of it even in a minor amount can be decisive in terms of structure and properties of the new formed phases. This aspect of the studied materials needs further investigations.

The micrographs presented in Figs. 4, 5, 6, 7, 8 show the results of SEM-EDS analysis of the studied samples. The
Fig. 3 FTIR analysis of studied samples

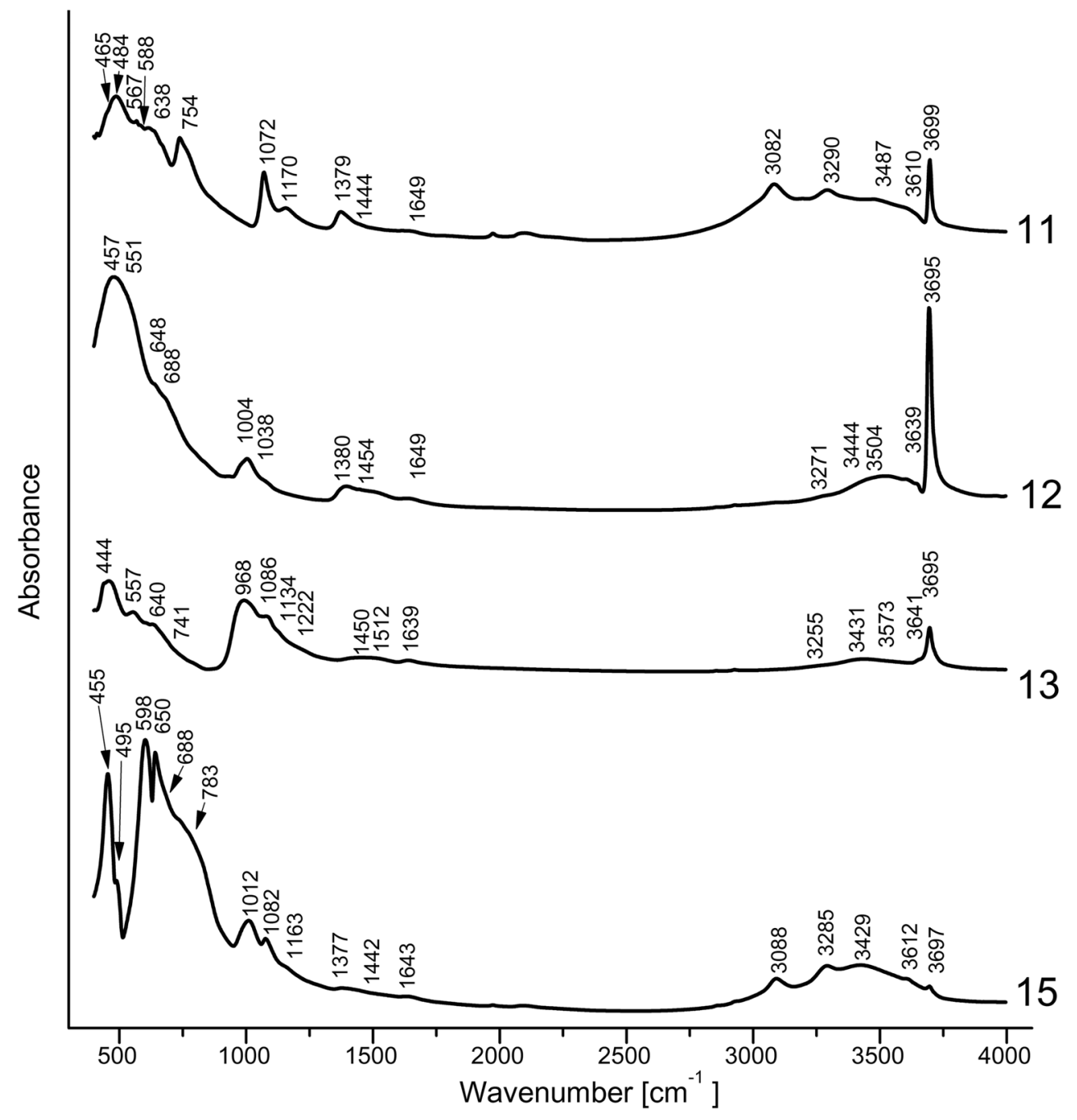




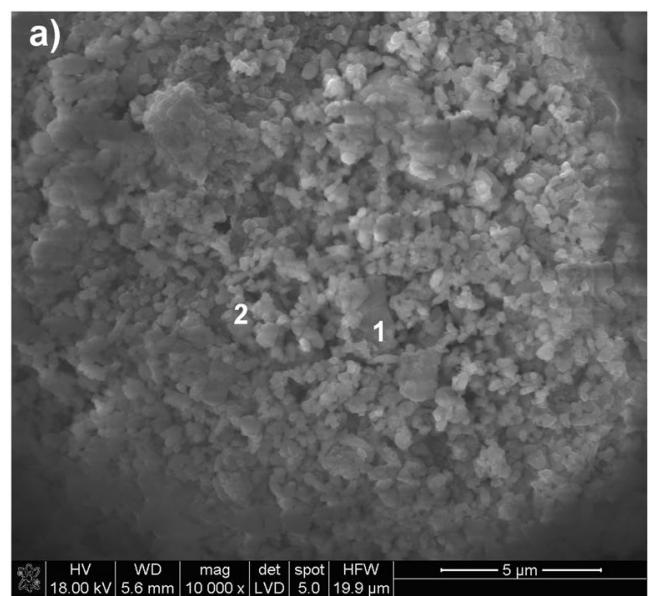

b)
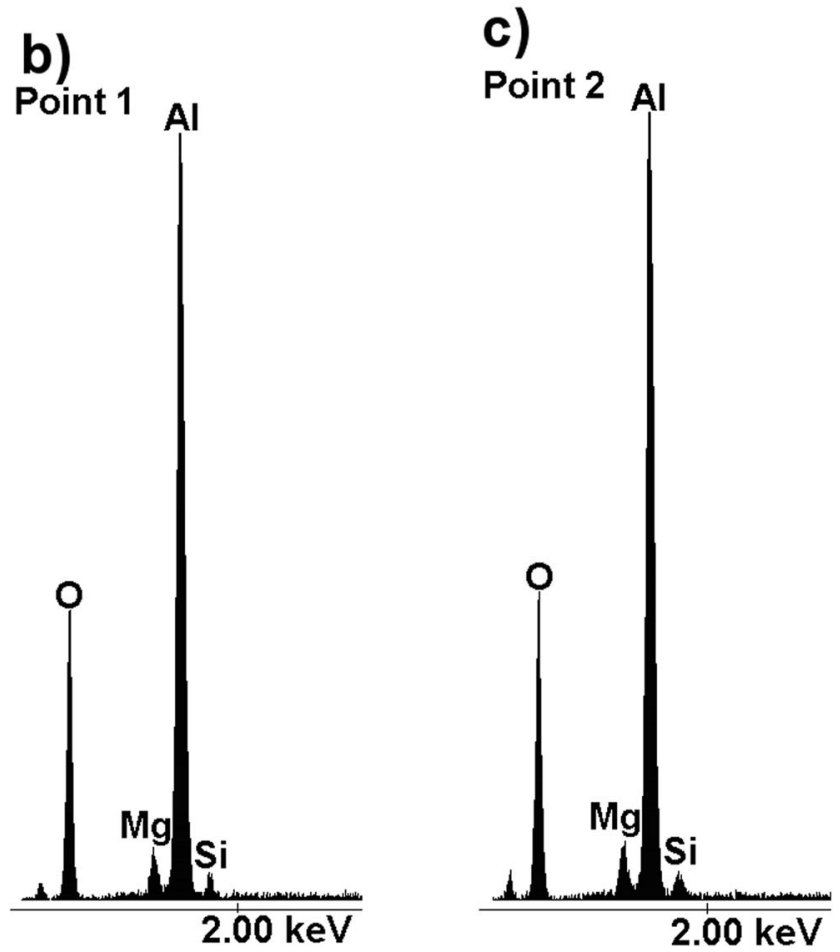

Fig. 4 SEM-EDS analysis of sample 15-larger aggregates richer in Al. a Microstructure of the sample. b, $\mathbf{c}$ EDS spectra of the sample in the microarea 1 and 2 respectively

microstructure of the samples is varied depending on chemical composition. Sample 15 (Figs. 4 and 5) exhibits granularshaped grains and homogeneous microstructure. According to EDS analysis, its chemical composition is varied, larger aggregates are composed mainly of $\mathrm{Al}_{2} \mathrm{O}_{3}$ with admixture of $\mathrm{MgO}$ and $\mathrm{SiO}_{2}$ (Fig. 4b, c) while smaller aggregates are richer in $\mathrm{MgO}$ (Fig. 5b, c). The SEM-EDS analysis of sample 13 (Fig. 6) reveals thin needle-like shaped crystals rich in $\mathrm{Mg}$, probably $\mathrm{Mg}(\mathrm{OH})_{2}$, surrounded by compacted rounded grains of the hydraulic phases composed of $\mathrm{SiO}_{2}$ and $\mathrm{MgO}$. Samples 11 (Fig. 7) and 12 (Fig. 8), with higher amount of $\mathrm{MgO}$ and $\mathrm{Al}_{2} \mathrm{O}_{3}$, have different microstructure from the previous

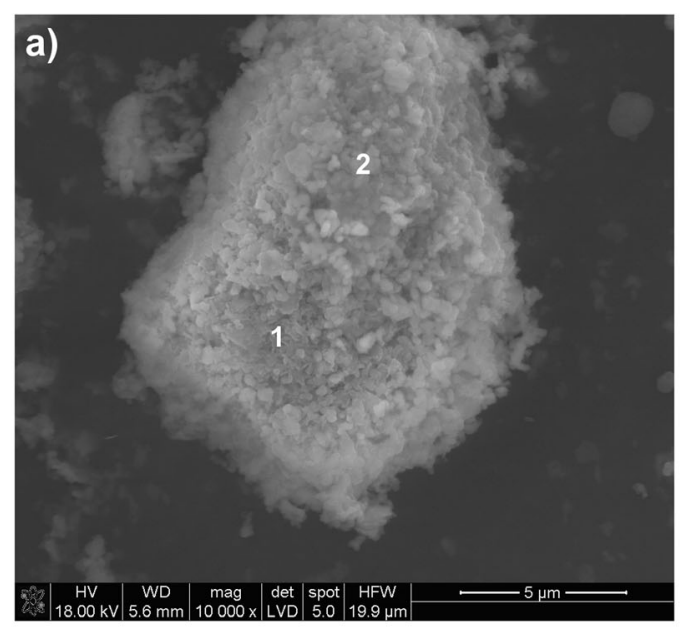

b)

\section{Point 1}

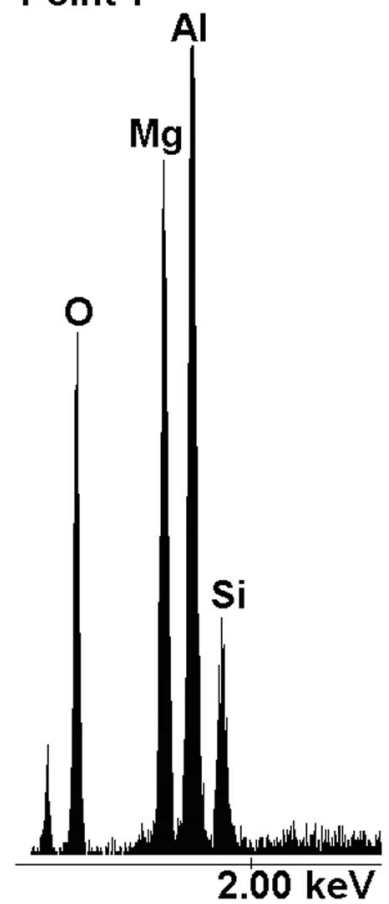

c)

Point 2

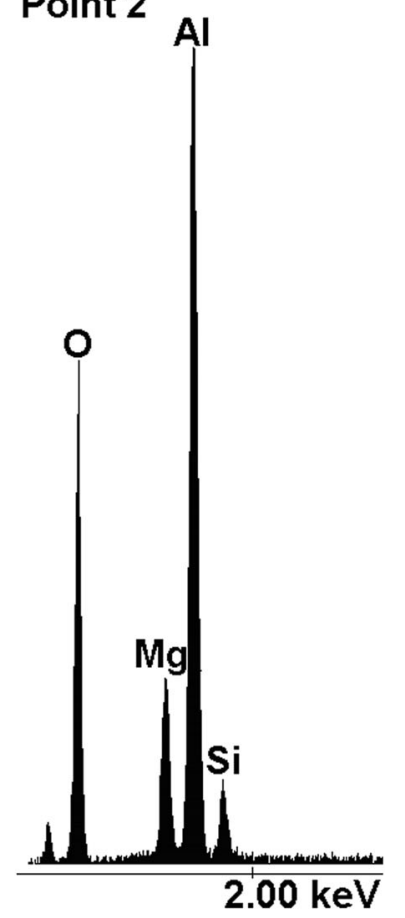

Fig. 5 SEM-EDS analysis of sample 15-smaller aggregates richer in $\mathrm{Mg}$. a Microstructure of the sample. $\mathbf{b}, \mathbf{c}$ EDS spectra of the sample in the microarea 1 and 2 respectively

samples. The SEM micrograph in Fig. 7a shows that two types of plate-like structures were formed as the major products of the hydrothermal treatment of sample 11. The big plate Alrich crystals and thin $\mathrm{Mg}$, Al-rich hexagonal plates were formed. The microanalysis of these smaller structures indicates the presence of the double magnesium and aluminum hydroxide (Fig. 7c). Similar morphology to sample 11 presents sample 12 (Fig. 8). Its microstructure is dominated by small plate structure, probably belonging to brucite crystals, as a main phase with some amount of $\mathrm{Al}$ which can suggest also 
Fig. 6 SEM-EDS analysis of the sample 13. a Microstructure of the sample. b-d EDS spectra of the sample in the microarea 1,2 , and 3 respectively
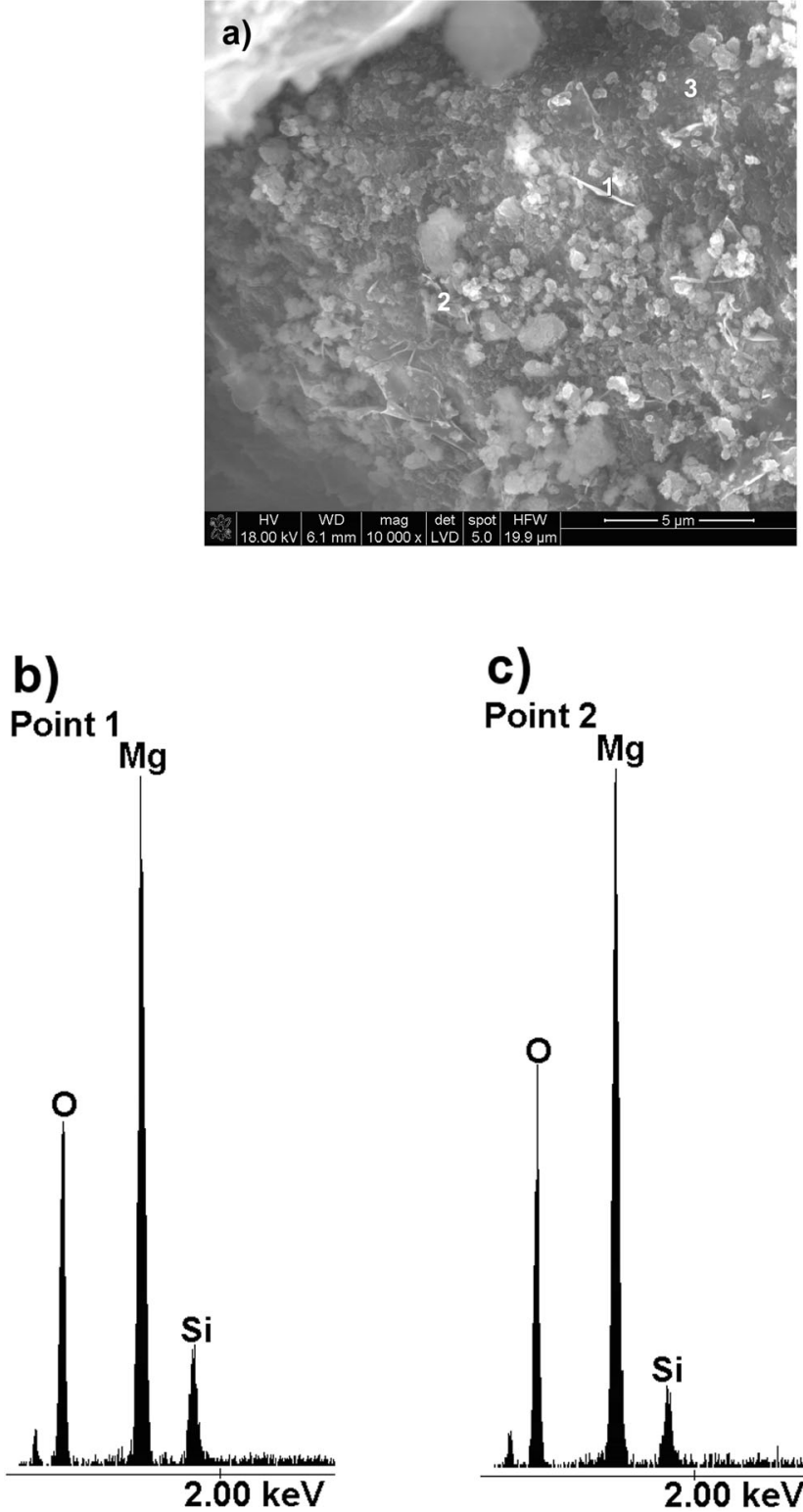

c)

Point 2

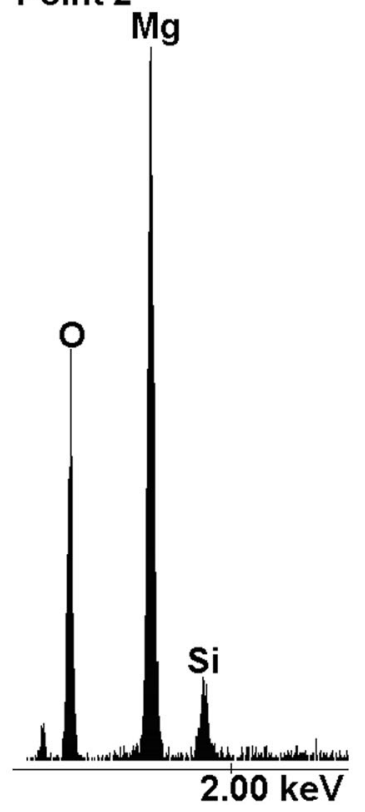

d)

Point 3

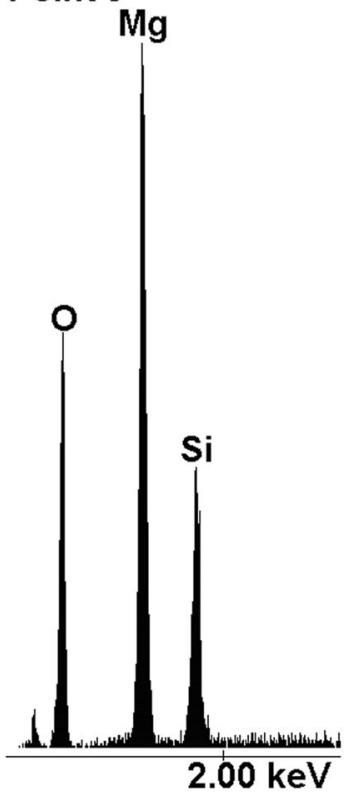

presence of double magnesium and aluminum hydroxide as a secondary phase.

\section{Summary and conclusions}

This work explains the reactivity of the binary $\mathrm{MgO}-\mathrm{Al}_{2} \mathrm{O}_{3}$ and $\mathrm{MgO}-\mathrm{SiO}_{2}$, and ternary $\mathrm{MgO}$ (rich) $-\mathrm{Al}_{2} \mathrm{O}_{3}-\mathrm{SiO}_{2}$ and $\mathrm{MgO}-\mathrm{Al}_{2} \mathrm{O}_{3}$ (rich)- $\mathrm{SiO}_{2}$ mixtures of reactive powders subjected to the hydrothermal treatment. The main goal of this approach is to simulate the thermal behavior of the hydrated cement-free pastes when exposed to heat treatment of largeformat precast monolithic refractories. Structure, phase composition, microstructure, and thermal stability of the hydrated materials were investigated by FT-IR, XRD, SEM-EDS, and
DSC-TG-EGA(MS) techniques, respectively. From the presented results, it was found that $\mathrm{MgO}$ affects the hydration behavior of $\mathrm{Al}_{2} \mathrm{O}_{3}$ and $\mathrm{SiO}_{2}$. Boehmite $(\mathrm{AlO}(\mathrm{OH}))$, brucite $\left(\mathrm{Mg}(\mathrm{OH})_{2}\right)$, and magnesium- and aluminum-layered double hydroxide-like phase $\left(\left[\mathrm{Mg}_{6} \mathrm{Al}_{2}(\mathrm{OH})_{18} 4.5 \mathrm{H}_{2} \mathrm{O}\right]\right)$ were formed via hydrothermal synthesis in the $\mathrm{MgO}-\mathrm{Al}_{2} \mathrm{O}_{3}-\mathrm{H}_{2} \mathrm{O}$ system, whereas $\mathrm{Mg}(\mathrm{OH})_{2}$ and magnesium silicate hydroxide (chrysotile) $\mathrm{Mg}_{3}\left[\mathrm{Si}_{2-x} \mathrm{O}_{5}\right](\mathrm{OH})_{4-4 x}$ were detected in the $\mathrm{MgO}-\mathrm{SiO}_{2}-\mathrm{H}_{2} \mathrm{O}$ system. Chrysotile $\left(\mathrm{Mg}_{3}\left[\mathrm{Si}_{2-x} \mathrm{O}_{5}\right](\mathrm{OH})_{4-4 x}\right)$ together with boehmite, brucite, and magnesium aluminum hydroxide hydrate $\left[\mathrm{Mg}_{6} \mathrm{Al}_{2}(\mathrm{OH})_{18} 4.5 \mathrm{H}_{2} \mathrm{O}\right]$ was formed in the $\mathrm{MgO}$ (rich) $-\mathrm{Al}_{2} \mathrm{O}_{3}-\mathrm{SiO}_{2}-\mathrm{H}_{2} \mathrm{O}$ binder system. In the system with the $\mathrm{Al}_{2} \mathrm{O}_{3}$ excess, two magnesium aluminum silicate hydroxides $\left((\mathrm{Mg}, \mathrm{Al})_{6}(\mathrm{Si}, \mathrm{Al})_{4} \mathrm{O}_{10}(\mathrm{OH})_{8}\right.$, $\left.\mathrm{Mg}_{5} \mathrm{Al}_{2} \mathrm{Si}_{3} \mathrm{O}_{10}(\mathrm{OH})_{8}\right)$, together with $\mathrm{MgAl}(\mathrm{OH})_{14} \mathrm{xH}_{2} \mathrm{O}$, 


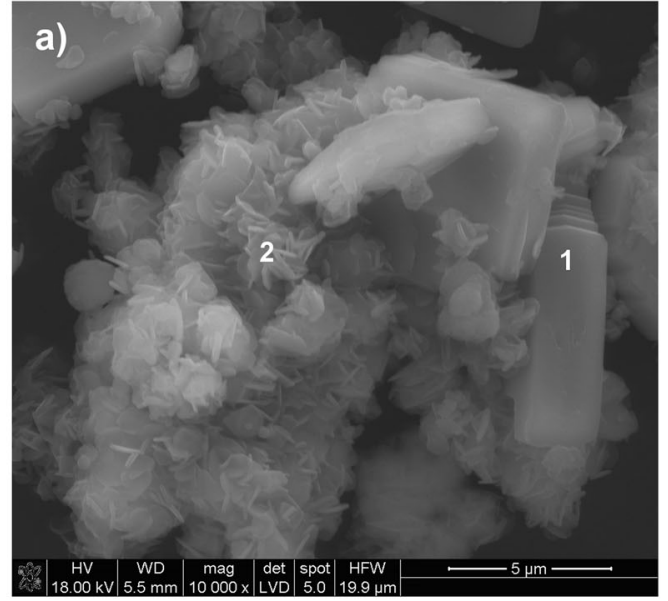

b)

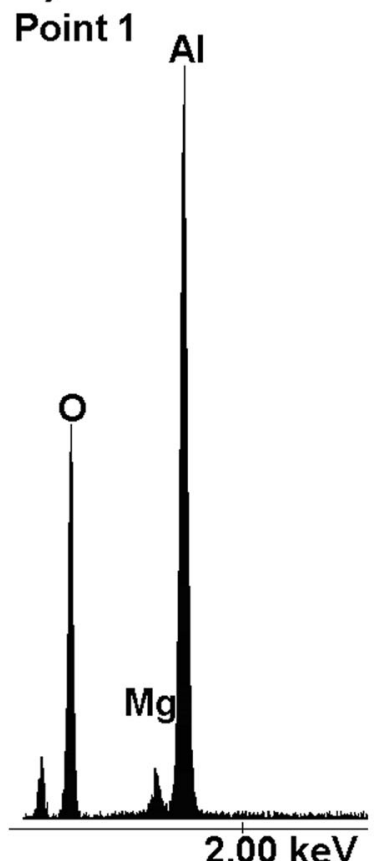

c)

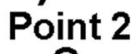

Point 2

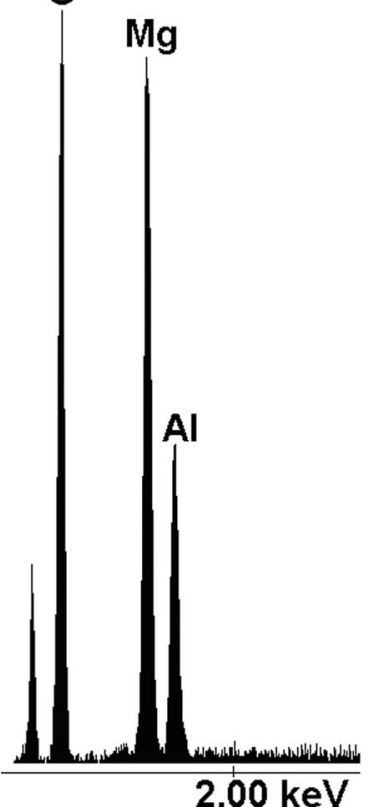

Fig. 7 SEM-EDS analysis of the sample 11. a Microstructure of the sample. b, c EDS spectra of the sample in the microarea 1 and 2 respectively

$\mathrm{Mg}(\mathrm{OH})_{2}$, and $\mathrm{AlO}(\mathrm{OH})$, were found in the $\mathrm{MgO}$ $\mathrm{Al}_{2} \mathrm{O}_{3}$ (rich) $-\mathrm{SiO}_{2}-\mathrm{H}_{2} \mathrm{O}$ binder system. The binding materials from the $\mathrm{MgO}-\mathrm{Al}_{2} \mathrm{O}_{3}-\mathrm{SiO}_{2}-\mathrm{H}_{2} \mathrm{O}$ phase system are versatile binders in a wide range of the castables. Depending on the chemical compositions, they can be utilized in basic, chamotte, and alumina castables; moreover, thanks to the elimination of cements containing $\mathrm{CaO}$, the new kinds of binders do not reduce the properties of the refractory materials. Considering the results of the performed analysis, it can be stated that during the hydrothermal treatment in the presence of $\mathrm{MgO}$, most the aluminum oxide transforms into boehmite and magnesium aluminum hydroxide hydrate.

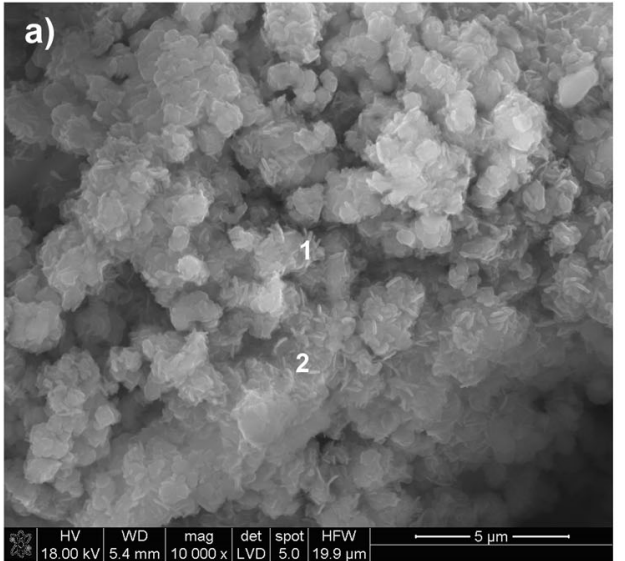

\section{b)}

\section{Point 1}

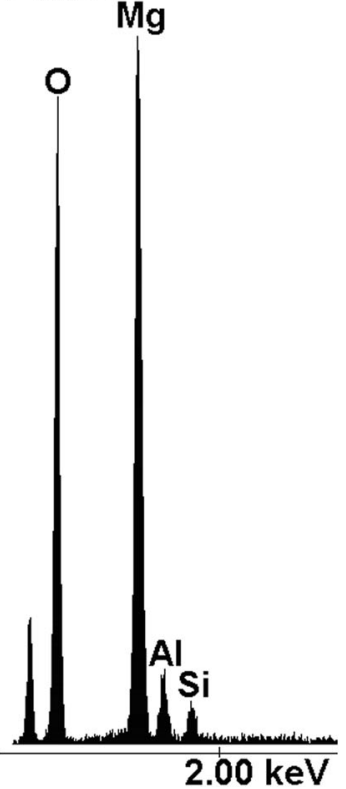

C)

Point 2

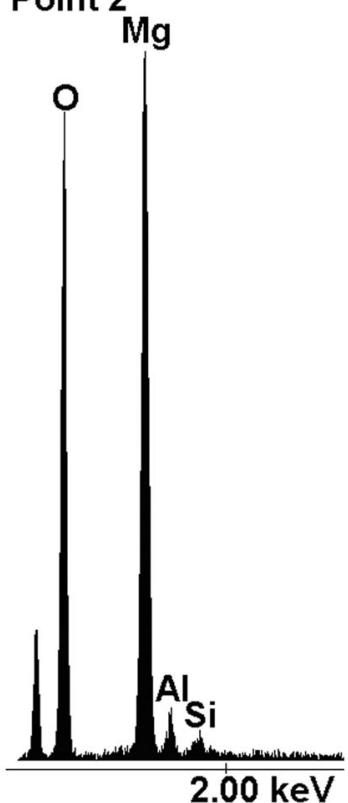

Fig. 8 SEM-EDS analysis of the sample 12. a Microstructure of the sample. b, c EDS spectra of the sample in the microarea 1 and 2 respectively

Moreover phases like double magnesium and aluminum hydroxide and M-S-H phase act as precursors of compounds like forsterite and spinel, decreasing their synthesis temperature. Faster synthesis of these compounds facilitates also formation of the ceramic bond in the castables. The creation of boehmite instead of gibbsite is another positive factor during the heat treatment of the materials based of this kind of binders, due to the elongated water release. Elongation of water release from the castables decreases internal pressure inside the heated material and prevents it against cracks and defects. Base on this study, it can also be noticed that even small changes in the composition can lead to a fundamental change in the properties of these materials. This is applied especially to aluminum oxide hydration and decided upon phase composition of the studied materials. 


\section{Highlights}

1. Phases from $\mathrm{MgO}-\mathrm{Al}_{2} \mathrm{O}_{3}-\mathrm{SiO}_{2}$ phase system are very promising binders in refractory materials.

2. Hydrothermal treatment approximate conditions during heat treatment of the refractory castables.

3. During the process boehmite and double aluminium magnesium hydroxide is creating.

4. The factor which decided about reactivity of aluminium and silica oxides in studied conditions is probably content of magnesium oxide, which influence on $\mathrm{pH}$ of the samples.

Acknowledgments This study was founded by The National Centre for Research and Development within the framework of LIDER VIII project No. LIDER/5/0034/L-8/16/NCBR/2017.

Open Access This article is distributed under the terms of the Creative Commons Attribution 4.0 International License (http:// creativecommons.org/licenses/by/4.0/), which permits unrestricted use, distribution, and reproduction in any medium, provided you give appropriate credit to the original author(s) and the source, provide a link to the Creative Commons license, and indicate if changes were made.

\section{References}

1. Da Luz, A.P., Braulio, M.A.L., Pandolfelli, V.C.: Refractory castable engineering. F.I.R.E. Compendium Series. Göller Verlag $\mathrm{GmbH}$, Baden-Baden (2015)

2. Poddar, D.D., Mulkhopadhyay, S.: Spinel-bonded basic castables in relation to spinel formation agents. Inteceram. 51(4), 282-288 (2002)

3. Sandberg, B., Mosberg, T.: Ceramic Transactions vol. 4: Advances in refractories technology. The American Ceramic Society Inc., Westerwille (1989)

4. Madej, D., Ortmann, C., Szczerba, J., Jacewicz, M.: Calorimetry and other methods in the studies of reactive magnesia-hydratable alumina-microsilica hydrating mixtures. J Therm Anal Calorim. 126, 1133-1142 (2016)

5. Singh, A.K., Sarkar, R.: High alumina castables: a comparison among various sol-gel bonding systems. J Aust Ceram Soc. 53, 553-567 (2017)

6. Szczerba, J., Prorok, R., Śnieżek, E., Madej, D., Maślona, K.: Influence of time and temperature on ageing and phases synthesis in the $\mathrm{MgO}-\mathrm{SiO}_{2}-\mathrm{H}_{2} \mathrm{O}$ system. Thermochim Acta. 567, 57-64 (2013)

7. Brew, D.R.M., Glasser, F.P.: Synthesis and characterization silicate hydrate gels. Cem Concr Res. 35, 85-98 (2005)

8. Mascolo, G., Marino, O., Cantarelli, A.: Crystallization field in the MgO- $\mathrm{Al}_{2} \mathrm{O}_{3}-\mathrm{H}_{2} \mathrm{O}$ system below $200^{\circ} \mathrm{C}$. Trans J Br Ceram Soc. 79(1), 6-10 (1980)

9. Madej, D.: Size-dependent hydration mechanism and kinetics for reactive $\mathrm{MgO}$ and $\mathrm{Al} 2 \mathrm{O} 3$ powders with respect to the calcia-free hydraulic binder systems designed for refractory castables. J Mater Sci. 52, 7578-7590 (2017)

10. Yang, W., Kim, Y., Liu, P.K.T., Sahimi, M., Tsotsis, T.T.: A study by in situ techniques of the thermal evolution of the structure of a $\mathrm{Mg}$ Al-CO3 layered double hydroxide. Chem Eng Sci. 57, 2945-2953 (2002)

11. Kloprogge, J.T., Ruan, H.D., Frost, R.L.: Thermal decomposition of bauxite minerals: infrared emission spectroscopy of gibbsite, boehmite and diaspore. J Mater Sci. 37, 1121-1129 (2002)

12. Viti, C.: Serpentine minerals discrimination by thermal analysis. Am Mineral. 95(4), 631-638 (2010)

13. Frost, R.L., Kloprogge, J.T.: Infrared emission spectroscopic study of brucite. Spectrochim Acta Part A. 55, 2195-2205 (1999)

14. Aisawa, S., Hirahara, H., Uchiyama, H., Takahashi, S., Narita, E.: Synthesis and thermal decomposition of Mn-Al layered double hydroxides. J Solid State Chem. 167, 152-159 (2002)

15. Frost, R.L., Locos, B.O., Ruan, H., Kloprogge, J.T.: Near-infrared and mid infrared spectroscopic study sepiolites and palygorskites. Vib Spectrosc. 27, 1-13 (2001)

16. Ristić, M., Czakó-Nagy, I., Musić, S., Vértes, A.: Spectroscopic characterization of chrysotile asbestos from different regions. J Mol Struct. 993, 120-126 (2011)

17. Nied, D., Enemark-Rasmussen, K., L'Hopital, E., Skibsted, J., Lothenbach, B.: Properties of magnesium silicate hydrates (M-SH). Cem Concr Res. 79, 323-332 (2016)

18. Tarte, P.: Infra-red spectra of inorganic aluminates and characteristic vibrational frequencies of $\mathrm{AlO} 4$ tetrahedra and $\mathrm{AlO} 6$ octahedra. Spectrochim Acta A Mol Spectrosc. 23(7), 2127-2143 (1967)

19. Xu, Z.P., Lu, G.Q.: Hydrothermal synthesis of layered double hydroxides (LDHs) from mixed $\mathrm{MgO}$ and $\mathrm{Al} 2 \mathrm{O} 3$ : $\mathrm{LDH}$ formation mechanism. Chem Mater. 17, 1055-1062 (2005)

Publisher's note Springer Nature remains neutral with regard to jurisdictional claims in published maps and institutional affiliations. 